\title{
Consumer Protection in South Africa: Challenges and Opportunities for Furniture Retailers in Cape Town, South Africa
}

\author{
Virimai Victor Mugobo \\ Department of Retail Business Management, Faculty of Business, \\ Cape Peninsula University of Technology, South Africa \\ Email: mugobov@cput.ac.za
}

\author{
Portia Malunga \\ Department of Entrepreneurship and Business Management, Faculty of Business, \\ Cape Peninsula University of Technology, South Africa \\ Email: malungaportia@gmail.com
}

\section{Doi:10.5901/mjss.2015.v6n1p224}

\begin{abstract}
Five years ago, the government of South Africa enacted the Consumer Protection Act which is a piece of legislation that seeks to protect consumers in their day-to-day dealings with retailers and other businesses. Heralded as the best consumer legislation in the world, the new Consumer Protection Act was received with mixed reactions by many businesses in general and furniture retailers in particular. This study therefore endeavoured to unearth the challenges and opportunities that this new consumer protection legislation provides to furniture retailers in Cape Town, South Africa. Using triangulation as the research methodology, semi-structured questionnaires were administered on 150 respondents from the population of study. 20 in-depth interviews were also carried out with customer service and branch managers from selected furniture retailers in Cape Town. The study found out that corporate chain (national) retailers are more aware of the Consumer Protection Act than small independent furniture retailers and that most retailers have already started implementing the new act. The study also found out that the new Consumer Protection Act poses major challenges for furniture retailers. These challenges include financial report instability, increased transaction costs and also the need for continuous staff development and training. On the other hand, this study also found that, if properly implemented, the new legislation may lead to an improvement in reputation, product quality, customer service and staff motivation. Many furniture retailers have thus taken a leading role in pushing the frontiers of their businesses in order to comply with the act. This study will add to the body of knowledge of customer service and consumer protection by uncovering some specific strategies which furniture retailers can adopt to counter the challenges and take advantage of the opportunities presented by the new Consumer Protection Act.
\end{abstract}

Keywords: Consumer, Protection, Legislation, Rights, Furniture Retailers, South Africa, Cape Town

\section{Introduction and Background}

As the world moves more and more towards the comprehensive protection of the consumer on the marketplace, South Africa has become one of the latest countries to join the consumer protection bandwagon by enacting legislation that supposedly transfers power from sellers to buyers. Ardic, Ibrahim and Mylenko (2011) argue that "government intervention and regulation in the area of consumer protection is justified on the basis of inherent information asymmetries and power imbalances in markets, with producers or service providers having more information about the products or services than the consumers". In 2009, the government of South Africa, after years of consultations and discussions with various stakeholders, enacted the Consumer Protection Act (CPA). Esser (2009) postulates that the CPA seeks to promote a fair, accessible and sustainable marketplace for consumer products and services and will thus improve the relationship between consumers and businesses. This study therefore sought to identify the challenges and opportunities faced by retailers in the furniture industry as a result of the enactment of the CPA in South Africa. Jagger (2006) elucidates that market dynamics in South Africa and across the world have contributed to the introduction of legislation to protect consumers. He further notes that the market is changing due to different factors such as the continuous introduction of new products, the changing behaviour of consumers, increasing competition across all industries and globalisation and these changes necessitate the need for laws that protects consumers.

Consumer protection has thus emerged as critical issue in South Africa. Heyns (2011) states that in order to keep 
abreast with global trends, it is imperative for South Africa to continuously revise its consumer protection legislation. He further notes that the continued revision of consumer protection legislation aims to ensure that the legislation in line with the Consumer Bill of Rights which is the international law that protects the rights of consumers across the globe and South Africa is a signatory to this law. By protecting consumers, the government seeks to ensure that consumers get quality and safe products through fair business practices by all the players on the market.

According to the Department of Trade and Industry (DTI) (2009) one of the major drivers for the need to enact new consumer protection legislation is the low level of literacy in the country especially in the rural areas. With little education, many consumers do not fully understand their rights and are thus susceptible to exploitation by businesses. Other issues that compelled the introduction of the new legislation include the rampant price fixing on the market, the marketing of products of poor quality and the bureaucratic channels that a consumer had to go through in order to raise a complaint against a business and for the complaint to be adjudicated upon by the relevant authority.

Lastly, globalisation has also been identified as a contributing factor for the need to protect consumers as goods produced in one country are marketed in several countries and the responsibility for poor quality has thus become difficult to apportion. In this regard, Fitzroy (2005) points out that as a result of accelerating globalisation, the traditional industry boundaries for retailers have now been blurred due to deregulation and massive technological changes. This scenario thus increases intra and inter country competition amongst retailers as they compete for the global market and leading to the need for governments to ensure fair business practices and the protection of the consumer on the market.

Consumer protection is not a new concept in South Africa and various acts of parliament have been passed in the country during the past decades. According to Maseti (2009) the first notable act which sought to protect consumers in South Africa was the Merchandise Marks Act of 1941. This Act regulated the marking of merchandise and of coverings in or with which merchandise was sold and the use of certain words or emblems by businesses.

Maseti (2009) also notes that in 1960 the Business Names Act was promulgated. The act stated that no person shall carry on any business under any name, title or description which includes the words "government", "state", "United Nations". The Sales and Service Matters Act of 1964 provided control of the sale of goods and rendering of services and other incidental matters. The Price Control Act of 1964 sought to control the prices that sellers charged for their goods and services. The act thus sought to protect consumers against overpricing by sellers. The Trade Practices Act of 1976 sought to protect consumers against false or misleading advertisements.

According to Maseti (2009), the Consumer Affairs (Unfair Business Practices) Act of 1988 provides a framework to protect consumers against "unfair business practices" which are defined as "...any business practice which directly or indirectly has or is likely to have the effect of harming relations between business and consumers, unreasonably prejudicing any consumer, deceiving any consumer or unfairly affecting any consumer" (ibid).

It is more than apparent that consumer legislation is not a novel concept in South Africa. However, over the years, consumer protection has remained largely unregulated with dispersed and disjointed pieces of legislation. This scenario created a fertile ground for the abuse of consumer rights and exploitation of consumers by sellers of goods and services. Consumers also did not have adequate platforms for their complaints to be heard and to be adjudicated upon. The CPA was thus enacted with the sole purpose of protecting consumer rights on the market. The DTI (2009) notes that the main purpose of the CPA is to "promote fairness, openness and good business practices between suppliers of goods and services and consumers of these goods and services". The Act therefore sets out the minimum requirements to ensure adequate consumer protection in South Africa. This act constitutes an overarching framework for consumer protection and all other laws which govern the relationship between buyers and sellers on the market, (Maseti 2009).

Wentzel (2008) propagates that the CPA replaces many laws currently regulating consumer protection with a single comprehensive framework for protecting consumer rights in South Africa. The Act builds on many principles contained in the National Credit Act (NCA) but extends to all consumer-facing businesses. Issues such as unfair contract terms, product liability, disclosure and pricing are regulated by the Act.

Jacobs, Stoop \& Niekerk (2010) concur with Wentzel (2008) when they underscore that the CPA's far-reaching provisions regarding the marketing of goods and services cover almost every imaginable scenario from consumer loyalty programmes and promotional competitions to referral selling. The CPA aims to rid the market of unethical trading practices, unsafe products and unfairly discriminatory marketing.

Jacobs et al. (2010) further posit state that the CPA generally applies across most industries involved in the supply of goods or services in the ordinary course of their business (unless an exemption applies) and also to franchise arrangements. The terms "supplier", "supply", "consumer", "goods" and "services" are defined more broadly in the Act than in common parlance (ibid).

After the enactment of the CPA in 2009, a number of businesses across many economic sectors in South Africa have been lobbying the government to amend or even repeal the CPA arguing that it is not good for business. Despite 
the South African consumer arguably emerging as the most protected consumer in the world as result of the new law, many businesses however contend that this legislation will be detrimental to their operations, profitability and ultimately their sustainability. It is this paradox that compelled the researchers to execute this study in order to establish the opportunities and challenges that furniture retailers will face as a result of the enactment of the CPA. The study therefore sought to establish how this new piece of legislation will impact on furniture retailers in general, and the specific challenges and opportunities that the legislation presents to the furniture retailing industry in particular. The following section provides a literature review of consumer protection.

\section{Literature Review}

Consumer protection is a concept which has existed for ages. It refers to the laws and regulations that govern the relationship between service providers and consumers. According to PriceWaterhouseCoopers (2011) "consumer protection refers to a range of regulatory and non-regulatory measures that seek to address a failure in the private market that leaves consumers especially vulnerable to financial loss". Piet (2002) propagates that consumer protection, as known today, has roots even in the daily lives of the Stone Age cave men who had the right to return to the seller any product they found to be unsatisfactory. However, Badler (2007) reveals a new dimension of consumer protection in the modern age when he postulates that consumer protection is about implementing consumer rights so as to ensure what is just, good or proper when dealing with consumers as well as ensuring that consumers are protected from harm or wrong doing when dealing with a provider of a service or a distributor of a product.

Haider (2010) further elaborates that consumer protection is about ensuring that consumers are shielded from various unfair trade practices. The purpose of such protection is to avoid the exploitation of consumers on the marketplace and eliminate various business malpractices. The DSG International (2002) concurs with this assertion and notes that in a totally open uncontrolled market, rogue traders could mis-describe products deliberately; sell damaged, unsafe or unfit products hence the need to have consumer protection in a marketplace.

Herre (2005) points out that consumer protection governs the marketplace by safeguarding the weaker party in any transaction. He further underscores that developing mandatory rules is just one of the many ways to protect this weaker party. One important addition or alternative is to regulate situations where one party takes advantage of the weaker party's lack of bargaining skill or inexperience. It is evident that Herre (2005) acknowledges that consumer protection is essential and it is through regulations that consumers are protected.

Singh (2012) asserts that consumer protection is universally accepted, the consumer has a right to be provided with all relevant information in order to avoid exploitation and make a considered choice in availing of products and services from the market. These rights are well-defined, both in local and worldwide markets. Allen (2010) outlines that although there are policies in place to ensure fair trade, consumers should be aware that these policies do not guarantee them that they are always right as there is that misconception amongst consumers. The laws afford reasonable redress to those with a genuine grievance, but defend retailers that trade lawfully. While some aspects of consumer law provide clearly defined remedies in specific circumstances, much of it is merely a set of guidelines for dispute resolution (ibid).

Though the above definitions differ, it is evident that all the authors acknowledge that the primary objective of consumer protection is to ensure that there is fairness and justice in the marketplace through the enactment of relevant legislation.

\subsection{The Consumer Protection Framework}

Ardic et al (2011) point out that "a consumer protection framework generally includes the introduction of greater transparency and awareness about the goods and services, promotion of competition in the marketplace, prevention of fraud, education of customers, and elimination of unfair practices".

According to Ardic et al (2011), different countries apply different frameworks in terms of consumer protection and nature of the framework adopted by a particular framework is dependent on the country's legal environment and a number of other factors such as the economic system, level of literacy, the competitive environment and so on. However, a basic consumer protection framework hinges on three basic factors. Firstly, the framework must clearly encompass and denote the laws and regulation that govern the relationship between buyers and sellers. Secondly, the framework must specify how the rules and regulations are going to be enforced on the marketplace, how disputes between consumers and sellers will be resolved and what remedies will be available to aggrieved parties. Finally, the framework must provide a mechanism to inform and educate consumers on their rights and obligations on the marketplace (ibid).

PriceWaterhouseCoopers (2011) points out that a consumer protection framework, through various policies and 
regulations has to fulfil certain key objectives. Firstly, the framework should provide a mechanism for protecting consumers from unfair, unjust or deceptive conduct and unsafe or somehow defective goods or services. Secondly, the framework should indicate the nature of assistance available to consumers when they suffer loss as a result of malpractices by sellers. Lastly, the framework should provide mechanisms to assist consumers to make better purchasing decisions on the marketplace by providing certain information or mandating certain terms or conditions (ibid).

\subsection{Reasons for Protecting Consumers}

There are several reasons why governments across the world continuously come up with laws and regulations to protect consumers. According to Hadfield, Howse and Trebilcock (2009), it is essential to protect consumers due factors such as technological changes and globalization which have expanded the range of consumer products available on the market thus making the formulation of consumer legislation inevitable. Haider (2010) also concurs with Hadfield et al (2009) when he avers that that it is essential to protect consumers so as to avoid business malpractices that are becoming more prevalent on the global market.

Davey (2010) propagates that consumer protection is important in every market, particularly in the South African context. The more vulnerable consumers are, the more protection is required. The new consumer legislation acknowledges the reality of many South African consumers in terms of their high levels of poverty, illiteracy and other forms of social and economic inequality; living in remote or low-density population areas; being minors, seniors or other similarly vulnerable consumers; having a limited ability to read and comprehend advertisements, agreements, instructions, warnings and so on as a result of low literacy levels, vision impairment or language impediments. All these factors contributed immensely to the need for the government to come up with new legislation.

Day (1977) further reveals that there has been a manifestation of the growth of consumerism in the recent years, hence the increase in the volume of complaints made by consumers to businesses, consumer organisations and other supporting structures. This is because the expectations of consumers are continuously increasing as their needs are changing. Day (1977) further affirms that it is necessary to protect consumers against retailers who might engage in false advertising and hence mislead the expectation of consumers.

Ferreira (2009) concurs with Day (1977) when he elucidates that consumer protection legislation ensures that consumers can limit all types of unwanted direct marketing acts either by requiring or demanding that the marketer discontinues the marketing, or by choosing not to receive the marketing in the first place. The regulations allow consumers to completely stop direct marketing hence promoting privacy for customers.

Knowler (2011) suggests that consumer protection legislation assists in turning the status quo by giving the consumer the power to decide on the remedy because back in the old days consumers did not have a say on the type of compensation they got for defective goods. Wright (2012) suggests that consumer protection is essential for the purposes of filling information gaps as retailers would be required to disclose all the information necessary for a consumer to make a purchase decision. Wright (2012) further states that consumer protection legislation prevents the unlawful creation or acquisition of market power and failure of the competitive process.

Sutcliffe (2008) posits that consumer protection ensures that there is proper disclosure of information between the consumer and the seller. The legislation forces retailers to provide clear contracts in understandable language hence this protects consumers from entering into contracts which they do not fully understand. Mohammed (2009) highlights that consumer protection legislation places the onus on the supplier to always supply the consumer with honest information when marketing products and services and this will enable the consumer to make empowered decisions.

Perrealt (2007) underscores the need to protect consumers when he propagates that businesses must be guided by certain social and ethical norms. He further outlines that it is the moral responsibility of the business to serve the interests of consumers. Keeping in line with principle of consumer protection, it is the duty of producers and traders to provide the right quality and quantity of goods at fair prices to the consumers. Perrealt (2007) also elaborates that businesses have to serve consumer interests for their own survival and growth. On the other hand, consumer protection is not only essential for customers but it is also essential for traders as it ensures that their businesses survive in the long term (ibid).

\section{Research Methodology}

This study adopted a mixed-methods approach by combining both qualitative and quantitative research methods. Twenty in-depth interviews were conducted with various legal practitioners, business strategists and customer services personnel and branch managers in the furniture retailing industry. 150 semi-structured questionnaires were also administered on 
various respondents working in the furniture retailing industry. Purposive sampling was used to select the respondents who participated in the study. The quantitative data was analysed using the statistical package for social sciences (SPSS) whilst the qualitative data was analysed using Atlas. Ti 7., which is a computer assisted qualitative data analysis software (CAQDAS).

\section{Findings and Discussion}

This study was formulated around several research questions and therefore the findings and discussion will be articulated within the context of these research questions.

\subsection{Research Question 1: Are retailers aware of the new consumer protection legislation in South Africa?}

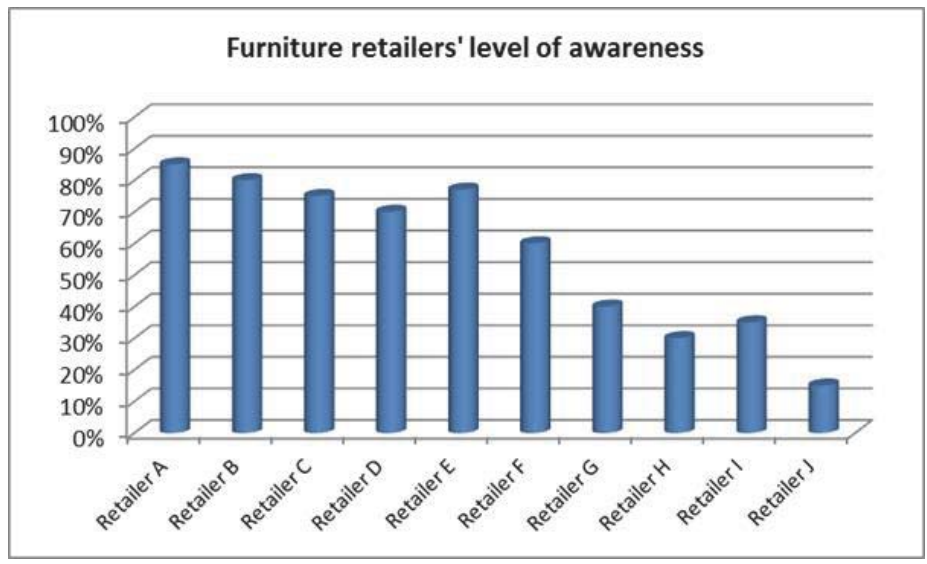

Figure 1: Level of awareness by furniture retailers

Retailers $A$ to $F$ represent corporate chain (national) retailers whereas retailers $G$ to $\mathrm{J}$ represent medium-sized retailers. It is clear that large, well established national retailers are more aware of the new consumer protection legislation than the relatively smaller medium-sized retailers. It is clear that national retailers generally endeavour to equip themselves with relevant legislation on consumer protection although they have a limited understanding of the law. From the above finding, it is apparent that small to medium enterprises (SMEs) are likely to have less awareness of the details of consumer protection laws than larger retailers and corporate chains.

\subsection{Research Question 2: Are consumers aware of the CPA?}

Table 1: Consumers Level of Awareness of the CPA

\begin{tabular}{|l|c|c|}
\hline Gender & Aware & Not Aware \\
\hline Men & 43 & 32 \\
\hline Women & 61 & 14 \\
\hline Total & 104 & 46 \\
\hline
\end{tabular}

Of the 150 consumers who were surveyed, $66 \%$ we aware of the CPA and $34 \%$ were not aware of the new act. However women seem to be more aware of the act ( $81 \%$ vs $57 \%)$ compared to their male counter parts. Customers demonstrate their awareness by complaining to the retailers and other relevant authorities in instances where they feel that their rights have been violated. It also imperative to note that in total, the level of awareness is about $69 \%$ and more than $30 \%$ of consumers are not aware of the act. It is clear that there is need for the government to increase its efforts in raising consumers' awareness of the CPA. 


\subsection{Research Question 3: Areas of Complaints}

Table 2: Areas of Complaints

\begin{tabular}{|l|c|}
\hline Nature of complaint & Prevalence of complaint \\
\hline Unfair market practices & $80 \%$ \\
\hline Product not conforming to advert & $64 \%$ \\
\hline Unclear information & $58 \%$ \\
\hline Unfair value & $70 \%$ \\
\hline Dishonest dealings & $74 \%$ \\
\hline
\end{tabular}

The $60 \%$ of the participants who are aware of the CPA have lodged complaints with the respective retailers in the past. Unfair business practices by retailers were found to be the main area of concern for consumers. One of the most common complaint that was highlighted was the failure by retailers to disclose the commitment that consumers are expected to meet in terms of the insurance of the goods they would have bought from the furniture retailer. Consumers complained that the initial instalment advertised for the goods was far much lower that the final instalment they will have to pay monthly when insurance is included.

\subsection{Research Question 4: What challenges have emerged as a result of the enactment of the CPA?}

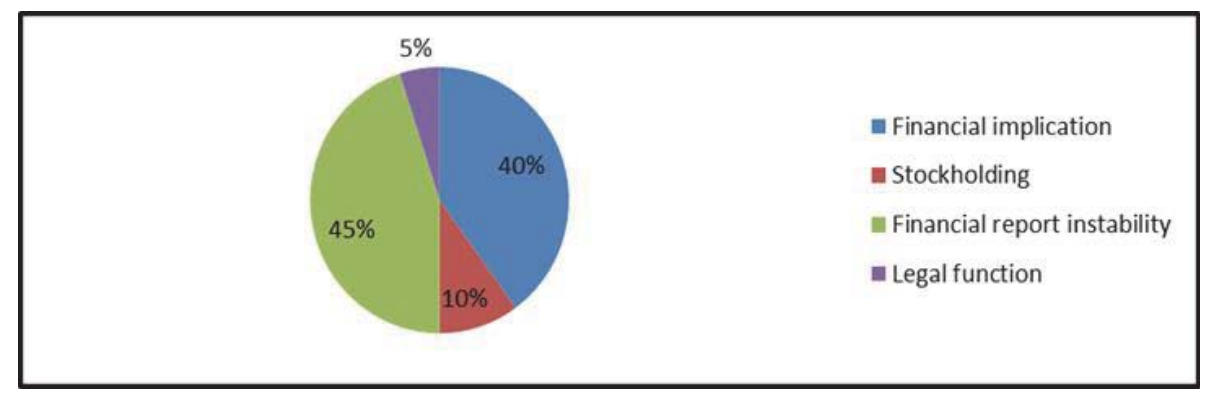

There are various challenges which furniture retailers are facing as a result of the enactment of the CPA. Most of the furniture retailers generally agreed that the CPA has affected their operations. The CPA placed a financial burden on the retailers as they increased their insurance cover to protect themselves against penalties and damages. The need to redraft contracts and train staff also added more costs to their operations. Stockholding has risen due to the high number of returns as consumers now have the right to choose to return goods during the "cooling off period" of five days as highlighted in the CPA. One major issue of concern for retailers is the fact that according to the CPA, a sale is only a sale after 15 days as consumers now have a right to return goods within 15 days of the day of purchase and get a refund. This requirement affects their financial reporting and creates uncertainty during the period in which the consumer is allowed by law to return the goods despite the fact that the retailers would have recorded the transaction as a concluded deal.

\subsection{Research Question 4: What opportunities does the CPA present to furniture retailers?}

Twenty interviews were carried out with respondents ranging from legal practitioners, business strategists and customer services managers in order to find out the opportunities that the CPA presents to furniture retailers. The following section discusses these opportunities.

\subsubsection{Positioning strategy}

Retailers who fully comply with the CPA can use that compliance as a marketing opportunity by informing their target market how much there are determined to ensure that consumers are getting value for their money when they buy goods and services from these CPA-compliant retailers. Compliance with the CPA can thus be used as evidence of the retailer's customer centrism and customer care. Compliance with the CPA should therefore be seen as a relationship-building exercise. 


\subsubsection{Improve Redress channels}

The CPA legislation ensure that retailers efficiently deal with customer complaints. It is imperative for furniture retailers to establish efficient and effective systems to address complaints by their customers in order to avoid litigation. Allowing customers to take them to the Consumer Commission or any court of law will not only be expensive in terms of legal costs but may also damage the reputation of the retailers through negative word-of-mouth communication and media reports. It is therefore critical for retailers to be able to solve problems that occur with their clients at the store level instead of letting the issues escalate to a stage where regulatory or legal action is taken.

\subsubsection{Business Guidelines}

It is also important for retailers to ensure that their staff members are knowledgeable of the CPA and its provisions. Retailers therefore need to train their staff members in terms of the provisions of the CPA and the level of compliance that is required. In this regard, retailers can develop manuals or operational guidelines for their staff members to follow. This will ensure that the retailers not only comply with the provisions of the CPA but that they also engage in consistent business practices thereby improving their business operations and relationship with their customers.

\subsubsection{Improve quality of goods}

According to the CPA, the responsibility for the provision of quality goods and services now rests with all members of the supply chain. In this case, a dissatisfied customer has the right to sue any member of the supply chain. In order to avoid a flood of consumer complaints and litigation, retailers and their supply chain partners are thus encouraged, if not compelled, to improve the quality of goods and services which they supply on the market. Retailers who meet or even exceed customers' quality expectations can thus use that as a source of differentiation and competitive advantage in their retail marketing strategy.

\subsubsection{Goodwill}

Compliance to the CPA also has the advantage of contributing positively to the reputation, image and goodwill of the retailers. Consumers are most likely to purchase from retailers who not only respect their rights but also engage in legal, fair and responsible business practices. The researchers therefore recommend that furniture retailers should comply with the provisions of the CPA in order to protect their brand reputation, brand equity and most importantly their long-term relationship with their clients. In this regard, compliance with the CPA should not be regarded as a business cost and a government requirement but rather as a key market requirement and a business investment.

\section{Conclusion and Implications}

It is more than apparent that the CPA is a comprehensive way to protect South African consumers in the current dynamic and complex market environment. This piece of legislation will have far reaching implications on the relationship between buyers and sellers of goods and services in the country. Therefore, it has to be given much consideration not only by furniture retailers but by every seller, making the awareness about the legislation essential as non-compliance with the act will have adverse repercussions. Generally, all retailers are aware of the CPA but the level of awareness differs from retailer to retailer due to their different organisational sizes and organisational attitude towards compliance. The size of a business thus determines the disposable resources a business has to educate its employees about this legislation.

On the other hand, as consumers become aware of their rights, they are in a better position to raise their grievances with furniture retailers making it critical for retailers to have efficient and effective redress channel. The level of consumer awareness of the CPA is troubling, though the sample size cannot be used to generalise the findings, $40 \%$ of the respondents were not aware of their rights and this makes them to be susceptible to unfair business practices by the furniture retailers. It is therefore imperative for the government and the regulatory authorities to come up with consumer education programmes in order to raise the level of consumers' awareness of the CPA.

It is more than apparent that much as the general perception on the market is that the CPA is detrimental to retail businesses, this study has revealed that the legislation has the potential of helping businesses to improve their operations, build and enhance their relationship with their customers, build their brand equity and ensure their long-term sustainability on the market. Despite the challenges that it possess to furniture retailers in terms of initial compliance, the 
CPA, if adopted and utilised by furniture retailers as a key market requirement, offers them many opportunities for business development and success. Compliance with the CPA is therefore not optional for furniture retailers.

\section{Recommendations for Further Study}

The study has raised pertinent areas for further study, as it brought to fore the awareness about the CPA, the challenges and opportunities that have emerged for furniture retailers as a result of the enactment of this legislation. Furthermore, studies can therefore be carried out to establish the strategies which furniture retailers in South Africa can adopt to ensure that all their employees are educated about the CPA; this is paramount for the long term survival of the furniture retailers. Further studies should also be carried out in order to determine how to increase consumers' level of awareness of the CPA.

Scholars have discussed what the CPA entails and who it affects but little research has been done on the various methods which furniture retailers are using to implement the act in their operations. It is imperative to embark on such a study so as to ascertain the real value the CPA is contributing in the marketplace and the best practices of implementing this legislation.

\section{References}

Advertising Standards Authorities. (2004). Advertising legislation. http://www.asasa.org.za/Default.aspx?mnu_id=10\#Supporters (11 September 2012)

Competition Commission (2008) Competition regulations. http://www.compcom.co.za/ (10 September 2012)

Allen, P. (2010). Consumer law: your rights explained. http://www.computeractive.co.uk/pcw/consumer- rights/1919607/consumer-lawrights-explained (15 September 2012)

Ardic, O. P., Ibrahim, J. A., and Mylenko, N. (2011). Consumer Protection Laws and Regulations in Deposit and Loan Services. Policy Research Working Paper 5536. World Bank

Badler, H. (2007). What are my consumer rights?. http://www.bizcommunity.com/Article/196/160/17811.html (5 September 2012)

Castillo, H. (2009). Research Population. http://www.experiment-resources.com/research-population.html (2 September 2012)

Chen, F. (2006). Mixed Approach. http://drupal.coe.unt.edu/sites/default/files/24/59/Johnson,\%20Burke\%20Mixed\%20Methods\%20 Research.pdf (5 September 2012)

Consumer Fair. (2010). Reasons for protecting consumers http://www.consumerfair.co.za/show.php?id=104 (15 September 2012)

Consumer Protection and Trade \& Development. (2005). What is consumer protection. http://www.cuts- india.org/what-is-consumerprotection-2.htm. (19 September 2012)

Consumer Rights Business Organisation. (2004). Consumer rights concept. http://business.gov.in/consumer_rights/meaning_ concept.php (10 September 2012)

Consumer Forum. (2009). Protecting South African consumers. http://mybroadband.co.za/vb/showthread.php/430361-SANCU-SouthAfrican-National-Consumer-Union. (2012)

Consumer Fair. (2012). Consumer fair issues. http://www.consumerfair.co.za/show.php?id=252 (5 September 2012)

Davey. V. (2010) . Online Marketing. http//www.ilead.co.za/blog/new-consumer-protection-act-2011-online-marketing.htm/2011 (1 September 2011)

Department of Economic Development. (2012). The informed consumer. http://www.westerncape.gov.za/other/2010/9/ consumerguideenglish.pdf(12 September 2012)

Department of Trade and Industry. (2009). Consumer protection guide. http://www.issafrica.org/crimehub/uploads/Consumer_ protection_PocketGuide.pdf

http://www.buanews.gov.za/rss/11/11033112451002 (10 September 2012)

DSG international . (2002). What is consumer protection? http://businesscasestudies.co.uk/dsg-international/meeting-and-exceedingconsumer-protection-laws-to-drive-competitive-advantage/what-is-consumer-protection-and-what-does-it-do.html (1 August 2012)

Edward, V. (2005). Voice for consumers. http://www.consumersinternational.org/who-we-are/we-are-50/history-of-the-consumermovement (21 April 2012)

Entrepreneur South Africa. (2011). Business start-up guidelines http://www.entrepreneurmag.co.za/advice/starting-a-business/start-upguide/the-consumer-protection-act/ (12 September 2012)

Esser, I. M. (2009) Stakeholder protection: the position of consumers. Tydskrif Vir Hedendaagse Romein- Hollandse Reg (THRHR). 72 (407)

Ferreira, C .(2009). Protecting Consumers in South Africa. http://www.hg.org/article.asp?id=5884 (2 September 2012)

Fitzroy, P. (2005). Strategic Management: Globalisation, London. Michael. M.

Gilbert, N. Researching social life. (2002). http://books.google.co.za/books?hl=en\&lr=\&id=Dla1q5i3NSEC\&oi=fnd\&pg=PA58\&dq=nonprobability+sampling+definition\&ots=0cEapFplay\&sig=pku2-Eww9PO-IDRRjpPToB1UtMO\#v=onepage\&q=nonprobability\%20sampling\%20definition\&f=false (10 September 2012)

Glendinning, A. (2011). Has the government gone too far. http://www.africanscene.co.za/2011/04/the-new- consumer-protection-act-has- 
the-government-gone-too-farl (1 September 2012)

Guarte, J \& Barrios, E. (2006). Estimation Under Purposive Sampling

Hadfield, G \& Trebilcock J.2007. Information-Based Principles for Rethinking Consumer Protection Policy http://www.springerlink.com/ content/uhgup5677284w727/ (7 September 2012)

Hadfield, G. K, Howse, R and Trebilcock, M. (2009). Good Practices for Consumer Protection and Financial Literacy in Europe and Central Asia: A Diagnostic Tool. The Word Bank, Washington

Haider, M J. (2010). DEF \& Importance of consumer protection. http://www.indiastudychannel.com/resources/128900-ImportanceConsumer-Protection.aspx (1 September 2012)

Herre, B .(2005). Consumer legislation.http://www.sgecc.uos.de/media/downloads/consumers_and_professionals.pdf (10 September 2012)

Heyns, H. (2002). Consumer Protection in South Africa. www.ggiforum.com/law/corporate-commercial- law/69-consumer-protectionsouth-africa-in-line-with-international-economic-trends. (1 September 2012)

Jacobs, W, Stoop, P. N \& Van Niekerk, R. (2010). Fundamental Consumer rights under the Consumer Protection act 68 of 2008: a critical overview and analysis. Potchefstroom Electronic Law Journal (13) 3

Jagger, N. (2006). Changing markets. www.meumannwhite.co.za/news-details/25/ (4 September 2012)

Knowler, W. (2011). Consumer complaints. http://www.saconsumercomplaints.co.zal (6 September 2012)

Lewis, V.2006. Defining business ethics. http://www.springerlink.com/content/9604533j32rl1n5m/ (15 September 2012)

Makhubo, C . (2009). Consumer complaints. http://www.pmg.org.za/odb/Consumer\%20Institute.htm (14 September 2012)

Marshall, C. and Rossman, G. (1989). Designing Qualitative Research, Sage, Newbury Park, CA.

Maseti, N. (2009).Trade and Industry.www.dit.gov.za (6 September 2012)

Mathe K . (2010). Consumer legislations. http://allafrica.com/stories/201003230067.html (4 September 2012)

Michalsons, W . (2011). The consumer protection act ahead. http://www.michalsons.co.za/the-consumer- protection-act-a-headsup/1382 (18 September 2012)

Michael, T. (2003). International perspective of consumer access to justice. http://papers.ssrn.com/sol3/papers.cfm?abstract_ id $=1214262 \&$ (13 April 2012)

Mike, S. (2012). Ultimate guide. www.starterpceo,co.za/2012/01/09/consumer-protection-act-ultimate-guide/onlineshopping (11 September 2011)

Mohammed, H .(2009). Consumer Protection the Winds of Change. http://www.jlesliesmith.com/articles/legal-articles/ConsumerProtection-Act--Winds-of-Change/default.aspx (8 September 2012)

Nios, S. (2006). Indian Laws. http://www.nios.ac.in/srsec319new/319EL24.pdf (19 September I 2012)

National Consumer Commission . (2011). Consumer Protection Summary. http://www.google.co.za/url?sa=t\&rct=j\&q=consumer+ protection+act+explanation+by+National+Consumer+Commission\&source=web\&cd=6\&ved=0CFsQFjAF\&url=http\%3A\%2F\%2Fw ww.standardbank.co.za\%2Fsite\%2F2011\%2FCPA\%2FCPA_long\%2520version.pdf\&ei=jgKhTbhMIOm0QWNpIHECA\&usg=AFQjCNGeSryWb3rOGmYZAT̄JP978jx6B2Hw (26 September 2012)

Office of trade . (2000). Consumer policies. http://www.oft.gov.uk/shared_oft/reports/consumer- policy/oft1058.pdf (11 September 2012)

Owens, K. Research Methods.2000. http://www.experiment-resources.com/research-population.html\#ixzz1tbuBEriMnda K. Owens://www.srl.uic.edu/seminars/Intro/introsrm.pdf. (27 September 2012)

Perreault, D. W. Advances in Consumer Research. Association for Consumer Research, Volume 04: 149-154.

Piet, J. History of consumer protection. (2002). http://www.consumerdaddy.com/a-12-history-of-consumer- protection.htm (12 September 2012)

PriceWaterhouseCoopers. (2011). Review of consumer protection in the travel and travel related services market. Department of the Treasury. Australia.

Ralph L. Day (1977). "Extending the Concept of Consumer Satisfaction", in NA - Advances in Consumer Research Volume 04, eds. William D. Perreault, Jr., Atlanta, GA: Association for Consumer Research, Pages: 149-154.

SAINFO Report . (2012). Who protects consumers? http://www.southafrica.info/services/consumer/consumer.htm (11 September 2012)

Schie, K. and Tromp, B . (2011). How the new consumer law protects you? http://www.iol.co.za/news/south- africa/how-the-newconsumer-law-protects-you-1.1020996\#.UDIJVKIIT64 (11 August 2012)

Schott, J. J. (2009).Challenges facing world trade. http://www.piie.com/publications/chapters_preview/66/1iie2350.pdf (16 September 2012)

Singh, B. (2012). Consumerism and its historical aspects with future perspective. http://shodhganga.inflibnet.ac.in/bitstream/ 10603/4464/13/13_chapter\%204.pdf

Sutcliffe, C. (2008). Consumer protection act. http://www.fpm.co.za/images/newsletter/consumer_protection_act.pdf (7 September 2012)

Williams, S . (2012). Good business practices. http://siteresources.worldbank.org/INTECAREGTOPPRVSECDEV/Resources/ GoodPractices_August2010.pdf

Wright, J. D. (2012). The antitrust/consumer protection paradox: two policies at war with each other. Yale Law Journal. George Mason University Law \& Economics Research Paper $12-45$ 